\title{
Articles
}

\section{THE PARTIAL-BIRTH ABORTION BAN ACT OF 2003 AND THE COMMERCE CLAUSE}

\author{
Allan Ides*
}

The Partial-Birth Abortion Ban Act of 2003 (PBABA), signed into law on November 5, 2003, by President Bush, ${ }^{1}$ bans the use of partial-birth abortions throughout the United States except when necessary to save the life of the mother. Specifically, section 1531(a) of PBABA provides:

Any physician who, in or affecting interstate or foreign commerce, knowingly performs a partial-birth abortion and thereby kills a human fetus shall be fined under this title or imprisoned not more than 2 years, or both. This subsection does not apply to a partial-birth abortion that is necessary to save the life of a mother whose life is endangered by a physical disorder, physical illness, or physical injury, including a life-endangering physical condition caused by or arising from the pregnancy itself. This subsection takes effect 1 day after the enactment. ${ }^{2}$

Section $\S 1531$ (b) defines the term "partial-birth abortion" 3 and extends coverage of the prohibition to any "individual" who per-

* Professor of Law and William M. Rains Fellow, Loyola Law School, Los Angeles. Thanks to Bill Araiza, David Burcham, Brietta Clark, Brannon Denning, Kurt Lash, Karl Manheim, Christopher May, and Robert Pushaw for their helpful comments and criticisms.

1. See 39 WEEKLY COMP. PRES. DOCS. 1540 (Nov. 5, 2003).

2. 18 U.S.C.A. \& 1531(a) (West 2004).

3. " $[\mathrm{T}]$ he term 'partial-birth abortion' means an abortion in which the person performing the abortion -

(A) deliberately and intentionally vaginally delivers a living fetus until, in the case of a head-first presentation, the entire fetal head is outside the body of the mother, or, in the case of a breech presentation, any part of the fetal trunk past the navel is outside the body of the mother, for the purpose of performing an overt act that the person knows will kill the partially delivered living fetus; and 
forms a partial-birth abortion, regardless of whether that person is a licensed medical practitioner. ${ }^{4}$ The phrase "partial-birth abortion" is highly charged and designedly so. It is the preferred usage of those who object to the dilation and extraction method of abortion as inhumane. I use the phrase "partial-birth abortion" throughout the text simply because it is language adopted by PBABA.

Congress passed similar bans in 1996 and 1997, both of which President Clinton vetoed. ${ }^{5}$ Three years after the second veto, and while Congress was considering a third version of the ban, the Supreme Court decided Stenberg v. Carhart ${ }^{6}$ holding that Nebraska's prohibition on partial-birth abortions unduly burdened a woman's right to choose. Despite Stenberg, congressional efforts to ban partial-birth abortions continued. Unquestionably Congress was fully aware of Stenberg and its potential constitutional implications when it revisited the issue and passed PBABA in 2003. Not too surprisingly, debate on the constitutionality of PBABA compared this statute with the ill-fated $\mathrm{Ne}$ braska statute, contesting whether PBABA also imposes an undue burden on a woman's right to choose. ${ }^{8} \mathrm{My}$ focus, however, is on a separate constitutional concern, namely, whether PBABA represents a valid exercise of the commerce power, the expressly identified authority under which the statute was enacted. ${ }^{9}$ On this seemingly significant question, the legislative record is relatively spare and the post-enactment debate largely silent.

(B) performs the overt act, other than completion of delivery, that kills the par-

tially delivered living fetus. .

18 U.S.C.A. $\$ 1531$ (b)(1) (West 2004).

4. 18 U.S.C.A. \$ 1531(b)(2) (West 2004).

5. H.R. DoC. No. 104-198, at 1 (1996) (President Clinton's veto message on the 1996 legislation); H.R. DoC. No. 105-158, at 1 (1997) (President Clinton's veto message on the 1997 legislation).

6. 530 U.S. 914 (2000).

7. See, e.g., Partial-Birth Abortion Ban Act of 2003, H.R. REP. No. 108-58, at 6-24 (2003) (discussing Stenberg); Partial-Birth Abortion Ban Act of 2003: Hearing before the Subcomm. on the Constitution of the House Comm. on the Judiciary, 108th Cong. 16-22, 25, 32 (2003) (same); Partial-Birth Abortion Ban Act of 2002: Hearing before the Subcomm. on the Constitution of the House Comm. on the Judiciary, 107th Cong. 2-3, 15, 19, 21-25, 30, 41, 47-48 (2002) (same).

8. It was on this basis that three district courts temporarily enjoined enforcement of PBABA. See Jonathan Groner, Challengers to Abortion Law Rally Around the Precedent, LEGAL TIMES, November 10, 2003, at 3; see also Nat'l Abortion Fed'n v. Ashcroft, 287 F. Supp. 2d 525 (S.D.N.Y. 2003); Carhart v. Ashcroft, 287 F. Supp. 2d 1015 (D. Neb. 2003).

9. See H.R. REP. No. 108-58, at 34 (2003) (PBABA constitutional authority statement). 
It is possible that the constitutionality of PBABA will be resolved without any reference to the commerce power. That possibility depends, however, on the stability of the Stenberg decision. While principles of stare decisis lend support to that stability, Supreme Court Justices have been known to shift and modify their views in the abortion context. Any variation between the Nebraska statute and PBABA could tilt a swing Justice in an unanticipated direction. Moreover, no one can accurately predict what the composition of the Court will be if and when PBABA arrives there for review. Thus, given the possibility of either doctrinal shift or personnel change at the Supreme Court, one cannot disregard other potentially dispositive constitutional issues. Certainly if the Stenberg majority does not hold, the question of congressional power might become central to the controversy. But perhaps more importantly, if the doctrine of enumerated powers is to be taken seriously, some thought ought to be given to the enumerated power that ostensibly serves as the basis for this enactment, if for no other reason than a respect for constitutional structure. Sound constitutional analysis dictates that the power to legislate be established before subjecting an act of Congress to external limits such as those imposed by the due process clause.

In what follows, I suggest that the constitutionality of PBABA is subject to serious doubt under current commerce clause doctrine. That is not to say that PBABA is "clearly" or "plainly" unconstitutional. The nuances of the Rehnquist Court's commerce clause doctrine are yet to be fully developed, and just as the Court's decision in Stenberg can be revised, so too can the Court's approach to the commerce clause. And, of course, reasonable minds can differ at the outer edges of application. But given the Rehnquist Court's most recent pronouncements on the commerce clause, one cannot help but conclude that PBABA represents, at best, a very poor effort to craft a piece of legislation in conformity with the obvious and applicable elements of constitutional doctrine.

\section{BASIC COMMERCE CLAUSE STANDARDS BRIEFLY CONSIDERED}

Pursuant to the commerce power, Congress may regulate both interstate commerce and certain activities that substantially affect interstate commerce. As to the regulation of interstate commerce itself, Congress is empowered to regulate the chan- 
nels and instrumentalities of interstate commerce, as well as things or persons in or using those channels or instrumentalities. ${ }^{\circ}$ Since the New Deal, the Court has not found a single "first category" exercise of the commerce clause to have exceeded the scope of the granted power. The same cannot be said of the second category. Under the category involving the regulation of matters that substantially affect interstate commerce, Congress does not direct its power at interstate commerce itself, but at matters outside commerce which nevertheless influence it. In this context, the modern Court has imposed discernable limits on congressional power, and one sitting Justice has even suggested that the category is without constitutional justification and ought to be abandoned." The first question, therefore, is whether PBABA regulates interstate commerce itself, and hence is relatively immune from judicial oversight, or whether it merely regulates matters that affect interstate commerce, potentially subjecting the statute to more active judicial oversight.

PBABA prohibits the performance of any partial-birth abortion "in or affecting interstate... commerce." 12 At first blush, this language may suggest that the statute represents an exercise of both aspects of the commerce power, the regulation of interstate commerce itself - the performance of a partial-birth abortion "in" interstate commerce-and the regulation of an activity that substantially affects interstate commerce-the performance of a partial-birth abortion "affecting" interstate commerce. Yet, it is doubtful that word "in" as used in PBABA signifies an attempt to regulate the channels or instrumentalities of interstate commerce. For one thing, it is not clear how a partial-birth abortion could be performed "in" interstate commerce in any but the most bizarre circumstances. Nor does the phrasing of the statute ("a physician who, in ... interstate ... commerce, knowingly performs a partial-birth abortion") sensibly apply to a physician who travels in interstate commerce and then performs a partial-birth abortion. Rather, the language connotes that it is the performance of an abortion itself that must take place in in-

10. United States v. Darby, 312 U.S. 100 (1941).

11. United States v. Morrison, 529 U.S. 598, 627 (2000) (Thomas, J., concurring); see also Jones v. United States, 529 U.S. 848, 860 (2000) (Thomas, J., concurring, joined by Scalia, J.) (expressing "no view" on whether the federal arson statute may constitutionally be applicd to all buildings used for commercial activities).

12. 18 U.S.C.A. $\$ 1531$ (a) (West 2004). The statute also pertains to matters in or affecting foreign commerce. There being no discernible difference between interstate commerce and foreign commerce for these purposes, the discussion in the text is fully applicable in the foreign commerce context as well. 
terstate commerce. In any event, the "affecting" interstate commerce language would seem perfectly suited to cover the "traveling" physician. Hence, I take the "in or affecting" language as embracing the performance of partial-birth abortions that in some manner affect interstate commerce. In other words, I will treat PBABA as an instance of the second category of commerce regulation, the so-called "substantially affects" test.

In United States v. Lopez ${ }^{13}$ and United States v. Morrison, ${ }^{14}$ the Court, for the first and then the second time in almost sixty years, restricted the breadth of the "substantially affects" test. In both cases, the Court held that Congress exceeded its commerce power by attempting to regulate matters that were noneconomic and that had at best an attenuated connection with interstate commerce. ${ }^{15}$ The two key questions under Lopez/Morrison are, first, whether the regulated activity is economic and, second, whether that activity substantially affects interstate commerce. These questions, although distinct, are intertwined in the sense that a negative answer to the first question, if not wholly dispositive, makes a negative answer to the second significantly more likely. Our answer to the second question may also be informed by the presence or absence of congressional findings or a statutory jurisdictional element, and by whether the regulated activity is one that has been traditionally left to the states.

I turn now to the first step of the Lopez/Morrison analysis, namely, the economic activity element.

\section{IS PERFORMANCE OF A PARTIAL-BIRTH ABORTION ECONOMIC ACTIVITY?}

Lopez held that gun possession in a school zone was not economic in any conceivable sense of that word. Morrison arrived at the same conclusion with respect to gender-based violence. ${ }^{16} \mathrm{~A}$ key factor in each case was the absence of an element of commercial exchange embedded in the respective statutory scheme. Had the Gun Free School Zones Act (GFSZA) required possession with the intent to sell, the economic nature of

13. 514 U.S. 549 (1995).

14. 529 U.S. $598(2000)$.

15. See Allan Ides, Economic Activity as a Proxy for Federalism: Intuition and Reason in United States v. Morrison, 18 CONST. COMMENT. 563 (2001).

16. I do not agree with Court's perception of the noneconomic nature of the crimes in Lopez and Morrison. See id. at 567-70. But regardless of my views, clearly Lopez and Morrison state the law to be applied in this context. Hence, whether a particular activity is "economic" can only be measured by the standards explicit and implicit in those cases. 
the regulated activity in Lopez would have been established. Interestingly enough, the defendant in Lopez was planning to sell his gun. That's why he brought it to school. But this fact was irrelevant to the Court's characterization of defendant's conduct as noneconomic since application of GFSZA did not require any such showing. In other words, GFSZA regulated only the noneconomic part of the defendant's transaction, namely, his possession of the gun, and simple possession, in the Court's estimation, was noneconomic. Stated somewhat differently, from a constitutional perspective, the fact that Lopez himself was on an economic mission was irrelevant in the absence of an economic statutory element.

The performance of a partial-birth abortion bears a close resemblance to the noneconomic possession of a gun. Just as possession of a gun can occur without any commercial element, the performance of a partial-birth abortion-indeed, the performance of any medical procedure - can be accomplished without a commercial overlay. It may be that most medical procedures, including partial-birth abortions, are done for hire. But this does not alter the simple fact that the procedure itself, unadorned by any commercial exchange, is noneconomic in the same sense as is gun possession. And just as GFSZA did not include an intent-to-sell element, PBABA does not require that the abortion be performed for hire. In other words, PBABA regulates only the noneconomic part of the transaction, namely, the performance of the medical procedure. If simple gun possession is noneconomic, then the performance of an abortion, unadorned by a commercial element, must be similarly characterized.

The constitutional analogy between gender-based violence and partial-birth abortions leads to the same conclusion. The Violence Against Women Act (VAWA), the statute at issue in Morrison, imposed no commercial overlay on its regulation of gender-based violence. Of course, an act of gender-based violence is in no way dependent on the presence of a commercial transaction. The same is true of a partial-birth abortion. By way of contrast, there are some activities, and some crimes, that are inherently commercial. Perez $v$. United States ${ }^{17}$ provides a useful example. In that case, the Court rejected a commerce clause challenge to a federal statute, the Consumer Credit Protection Act, which criminalized extortionate credit transactions. An ex-

17. 402 U.S. 146 (1971). 
tortionate credit transaction is inherently commercial since it involves the extension of credit. As a consequence, the Consumer Credit Protection Act can be fairly described as a regulation of economic activity and in this sense is quite distinguishable from VAWA. PBABA much more closely resembles VAWA in this regard than it does the Credit Consumer Protection Act. In other words, there is nothing inherently commercial about either performing an abortion or engaging in gender-based violence. As a consequence, neither activity is economic as the Court used that word in both Lopez and Morrison.

Does the fact that a physician performing a partial-birth abortion provides a service to the patient alter the conclusion that the regulated activity is noneconomic? After all, the provision of a service does represent a type of unilateral transfer of wealth, even when the service is provided gratis. Still, this type of "economic" transfer lacks the commercial characteristics the Court deemed critical in Lopez and Morrison. Hence, while gun possession, which involves neither service nor exchange of any kind, is distinguishable from the performance of abortion in this respect, the distinction has no constitutional significance. Neither activity is commercial; hence, neither is economic. As a consequence, the service character of a partial-birth abortion should make no constitutional difference unless the Court is inclined to extend its economic activity test beyond its current foundation.

The potential distinction between service activities and nonservice activities is further undermined when one compares the physician's service under PBABA to the gender-based violence regulated under VAWA. Clearly, gender-based violence cannot be characterized as a service. Rather than doing something "for" somebody, the perpetrator is doing something "to" somebody. Yet this verbal play between prepositions merely underscores the constitutional similarity between these activities. Both the performance of an abortion and the infliction of violence involve physical interaction between human beings. Moreover, the entire thesis of PBABA is that the performance of a partial-birth abortion is an act of violence. Indeed, the doctor is not being punished for the service he provides, but for the crime he commits when he kills the fetus. In other words, he is punished for what he does "to" the fetus. Thus, the prohibition of partial-birth abortions, under the reasoning of Morrison, surely falls into that category of punishing violent, noneconomic crimes beyond the reach of the commerce power. In short, the fact that the physi- 
cian provides a service does not alter the noneconomic nature of the activity under Lopez/Morrison.

An activity that is in itself noneconomic may still be treated as economic if its regulation is "an essential part of a larger regulation of economic activity, in which the regulatory scheme could be undercut unless the intrastate activity were regulated. ${ }^{18}$ The classic case is Wickard v. Filburn. ${ }^{19}$ There the Court upheld the power of Congress to regulate wheat grown and consumed on the farm on the theory that regulation of these activities was essential to the regulation of wheat sold in interstate and foreign commerce, a target of the Agricultural Adjustment Act of 1938. The Court in Filburn accepted the government's argument that the aggregate effect of wheat consumed on the farm "would have a substantial influence on price and market conditions." Just as the Filburn rationale was not applicable to GFSZA, there being no larger regulation of economic activity of which GFSZA was a part, nothing in PBABA suggests that the prohibition of partial-birth abortions is part of a larger regulation of economic activity. Rather, the partial-birth abortion prohibition is a standalone measure designed to address what its proponents see as an immoral act, independent of any larger economic or commercial considerations. In the words of the Lopez Court, "It cannot ... be sustained under our cases upholding regulations of activities that arise out of or are connected with a commercial transaction, which viewed in the aggregate, substantially affects interstate commerce." ${ }^{21}$ To rule otherwise would be to grant Congress a general police power like that of the states, and this is something the Court is quite unprepared to do. ${ }^{22}$

Of course, if PBABA applied only to abortions-for-hire, the resulting commercial overlay would transform the otherwise noneconomic act of abortion into economic act of abortion-forhire. Yet nothing in PBABA expressly imposes such a limiting construction. Perhaps one could interpret the phrase, "in or affecting interstate commerce," as designed to accomplish that end. There are, however, at least two obstacles to this interpretation. First and most pertinently, the language simply does not carry that meaning. In Justice Scalia's words, "A text should not be construed strictly, and it should not be construed leniently; it

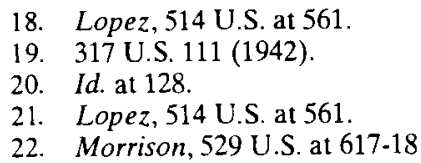


should be construed reasonably, to contain all that it fairly means." 23 The evident meaning of the "in or affecting" language pertains to the location of or consequences generated by the matter regulated, and not to the nature of the regulated activity.

The Rehnquist Court's decision in Jones v. United States supports this conclusion. ${ }^{24}$ At issue in Jones was the scope of a federal arson statute that prohibited the arson of a building "used in" interstate commerce or in an activity affecting interstate commerce..$^{25}$ In construing the statute to apply only to the arson of commercial buildings, the Court distinguished between a statute that broadly defined the crime "as the explosion of a building whose damage or destruction might affect interstate commerce" and one that required that the damaged or destroyed property "must itself have been used in commerce or in an activity affecting commerce." fecting interstate commerce" language would embrace both commercial and noncommercial activities - that is, all activities that might affect interstate commerce. In the latter context, however, the "used in" terminology limits the scope of the proscription to the destruction of commercial facilities. As the Jones Court phrased it, "The key word is 'used.",27 PBABA, quite clearly, contains no language limiting the scope of the affects test and, therefore, falls into that category of statutes that purport to embrace the broad array of activities, both commercial and noncommercial, that might affect interstate commerce. Since PBABA was enacted after the 2000 decision in Jones, we may fairly assume that Congress drafted PBABA in light of this judicially crafted distinction.

Second, and closely related, the key doctrinal development in Lopez and Morrison was the distinction between the nature of the regulated activity and its potential effect on interstate commerce. ${ }^{28}$ To interpret the phrase "in or affecting interstate commerce" as pertaining to the nature of the activity fails to account

23. See Antonin SCAlia, A Matter of Interpretation 23 (1997).

24. 529 U.S. $848(2000)$

25. 18 U.S.C. $\$ 844(i)(1994)$.

26. 529 U.S. at 854 .

27. Id.

28. Justice Breyer's dissent in United States $v$. Morrison rejected the majority's economic activity test, in part, because of the obvious fact that noneconomic activity can also substantially affect interstate commerce. 529 U.S. at 655, 657 (Breyer, J., dissenting). The majority did not deny this assertion; rather, it rested on the formal distinction between economic and noneconomic activity and on the historical fact that the Court had never validated a congressional regulation of noneconomic activity. 529 U.S. at 611 n.4. 
for this doctrinal separation and confuses the effect on interstate commerce with the nature of the activity being regulated. To adopt this broader interpretation would be to eviscerate both Lopez and Morrison, for if any activity that affects interstate commerce is by definition an economic activity, then the distinction between economic and noneconomic activity becomes irrelevant. In short, the "in or affecting interstate commerce" language cannot be fairly read as limiting the scope of PBABA to abortions-for-hire.

The congressional confusion on this score is reflected in the House report accompanying PBABA. ${ }^{29}$ According to that report, "[t]he provision of abortion services, including partial-birth abortions, is clearly commerce." ${ }^{30}$ For this proposition, the report relies on a statement of former Attorney General Janet Reno. That statement, however, was issued before the decision in Lopez, and, more importantly, is premised on the economic transactions related to the provision of those services. The authors of the report were, perhaps, making the same type of assumption when they stated, "the performance of a partial-birth abortion, as with the performance of any abortion, is an economic transaction in which a service is performed for a fee." ${ }^{31}$ Of course, this statement is both imprecise and incorrect. The performance of an abortion is itself noneconomic unless that performance is rendered for a fee. This lack of precision in the congressional report reflects a misunderstanding of Lopez and Morrison that may well have adversely affected the drafting of PBABA.

Of course, Congress could rewrite PBABA to include an "abortion-for-hire" requirement, but that possibility merely underscores the fact that Congress did not do so. Interestingly, Congress was notified of this problem early on in the legislative process. In testimony before the Senate Committee on the Judiciary, Professor Louis Seidman explained:

Here, as in Lopez, the regulated activity is not "economic." Having an abortion is no more a commercial activity than possessing a gun. True, most (although by no means all) abortions are purchased, and Article I probably does reach legislation that would prohibit the payment of money for certain types of abortions (at least in cases where an effect on inter-

29. The Partial-Birth Abortion Ban Act of 2003, H.R. REP. NO. 108-58 (2003).

30. Id. at 23.

31. Id. at 24 . 
state commerce can be shown). But most guns are also purchased. Just as Congress can regulate the interstate purchase of guns, but not the intrastate possession, so, it would seem, it can regulate the interstate purchase of abortions, but not the intrastate procedure itself.

Congress chose to ignore this concern. In any event, for present purposes, the only question is whether PBABA is constitutional, not whether a hypothetical statute yet to be drafted might itself pass constitutional muster.

\section{DOES THE NONECONOMIC CHARACTER OF THE ACT OF PERFORMING OF AN ABORTION PRECLUDE REGULATION OF THAT ACTIVITY PURSUANT TO THE COMMERCE POWER?}

The short answer is that it probably does, at least under the watchful eye of the current Court. Those seeking to invoke the commerce power in this context would do well to heed the words posted over Dante's Gate of Hell: "Lasciate ogne speranza, voi ch'intrate." 33 ("All hope abandon, ye who enter here.") True, neither Lopez nor Morrison imposed a categorical rule against the regulation of noneconomic activity. Yet the tenor of both decisions comes very close to making the barrier all but impenetrable. In the words of the Morrison Court, "While we need not adopt a categorical rule against aggregating the effects of any noneconomic activity in order to decide these cases, thus far in our nation's history our cases have upheld Commerce Clause regulation of intrastate activity only where that activity is economic in nature." 34 In Lopez, the Court stated the matter somewhat differently: "Where economic activity substantially affects interstate commerce, legislation regulating that activity will be sustained. ${ }^{35}$ Of course, this affirmative recognition of the power to regulate economic activity does not necessarily negate the power to regulate noneconomic activity, but given the context of this quotation, it is clear that the Court was attempting to draw a circle within which congressional power would be validated and outside of which the exercise of such power would, at the very least, be suspect. There is no hint in either Lopez or Morrison

32. The Partial-Birth Abortion Ban Act of 1995: Hearings Before the Senate Comm. on the Judiciary, 104th Cong. 190, 193 (1995) (prepared statement of Louis Michael Seidman).

33. Dante Alighieri, The Divine Comedy, The Inferno: Canto $3, l, 9$

34. 529 U.S. at 613 (emphasis added).

35. 514 U.S. at 560. 
that the Court is looking to alter this historical fact. Rather, both decisions tend toward the creation of an enclave of activity immune from congressional regulation. At the very least, the noneconomic nature of a regulated activity presents a strong presumption that the activity is beyond the reach of the commerce power, leading to a type of commerce clause scrutiny that may well be "strict in theory, but fatal in fact." 36

Of course, the Supreme Court hasn't said, "Never," and so the door to regulation of noneconomic activity pursuant to the commerce power is certainly not double-bolted. Let us assume then that the noneconomic character of the regulated activity is not wholly dispositive, that there remains at least a possibility, albeit remote, of overcoming the presumption of unconstitutionality. Presumably that possibility would require that the challenged statute be distinguishable in some significant way from the statutes at issue in Lopez and Morrison. There are four questions, each examined in Lopez and Morrison, that might serve as a basis for discovering a constitutionally relevant distinction: First, has regulation of the activity been traditionally left to the states? Second, did Congress make findings pertaining to the perceived effect of that activity on interstate commerce? Third, does the statute include a jurisdictional element? Fourth, does the activity substantially affect interstate commerce? I turn now to these questions to determine if PBABA can be distinguished effectively from GFSZA and VAWA.

\section{IS THE ACTIVITY REGULATED BY PBABA ONE THAT HAS BEEN TRADITIONALLY LEFT TO THE STATES?}

In Morrison, the Court explained its holding in part by observing that "[t]he Constitution requires a distinction between what is truly national and what is truly local."37 This quote, I believe, captures the essence of Lopez and Morrison. These decisions reflect an effort to cabin the power of the federal government by recognizing an enclave of traditional state authority insulated from federal interference. I have argued elsewhere that the economic activity test serves as a proxy for this reinvigorated

36. Gerald Gunther, The Supreme Court, 1971 Term-Foreword: In Search of Evolving Doctrine on a Changing Court: A Model for a Newer Equal Protection, 86 HARV. L. REV. 1, 8 (1972).

37. 529 U.S. at $617-18$. 
principle of federalism. ${ }^{38}$ Thus, one way to determine whether an activity is "truly national" or "truly local" is to examine the potential economic character of that activity. Noneconomic activity is presumptively (or perhaps definitively) "truly local" and hence beyond the power of Congress. A second way to measure the national/local distinction is more direct. Simply ask whether the regulation of the activity at issue has traditionally been left to the states. If so, principles of federalism may prevent Congress from invading this province of state prerogative. For example, in Morrison the Court found that the regulation of violent crime was truly a matter of local concern:

In recognizing this [distinction between what is truly national and truly local] we preserve one of the few principles that has been consistent since the [commerce] Clause was adopted. The regulation and punishment of intrastate violence that is not directed at the instrumentalities, channels, or goods involved in interstate commerce has always been the province of the States. Indeed, we can think of no better example of the police power, which the Founders denied the national Government and reposed in the States, than the suppression of violent crime and vindication of its victims. ${ }^{39}$

We have already concluded that the performance of a partial-birth abortion is noneconomic. Is the regulation of that activity also one that has been traditionally reserved to the states? In other words, is the regulation of this medical procedure something that can be fairly characterized as a truly local concern? I believe the answer to this question is "yes" for three reasons. First, as the sponsors of PBABA recognized, the activity being regulated - the performance of a partial-birth abortion - is a violent crime, namely, the killing of a fetus. ${ }^{40}$ The proscription applies not only to licensed medical practitioners, but also to any "individual" who performs the prohibited act. Moreover, the intrastate act of aborting a fetus is not directed at instrumentalities, channels, or goods involved in interstate commerce. In this sense, PBABA reaches into what the Morrison Court perceived as the quintessential example of state prerogative, namely, the

38. See Ides, supra note 15 , at $578-80$.

39. 529 U.S. at 617-18.

40. See The Partial-Birth Abortion Ban Act of 2003, H.R. REP. No. 108-58, at 5 (2003) (describing state laws proscribing partial-birth abortions as "criminal bans"); see also The Partial-Birth Abortion Ban Act of 1995: Hearing Before the Senate Comm. on the Judiciary, 104th Cong. 172, 173, 186 (1995) (prepared statement of Douglas W. Kmiec) (describing partial-birth abortions as homicides). 
suppression of violent crime, "which the Founders denied the National Government and reposed in the States." ${ }^{41}$ Second, in the Court's own words, albeit in a slightly different context, "the field of health care [is] a subject of traditional state regulation." 42 That is not to say that the regulation of economic activity within the field of health care is absolutely immune from federal regulation. ${ }^{43}$ But the regulation of the noneconomic aspects of medical procedures may well be, given both the tradition of state prerogative in this field and the absence of any "truly national" interest in this subject area. Third, the regulation of abortions, both before and after Roe $v$. Wade ${ }^{44}$ has remained the exclusive province of the states subject only to the Fourteenth Amendment. While Congress, in the exercise of its spending powers, ${ }^{45}$ has imposed limits on the federal funding of abortions, the actual regulation of abortions has remained a state prerogative.

In short, the activity regulated by PBABA is both noneconomic and, by tradition and constitutional design, a matter that has remained within state prerogative. In Morrison, the Court observed, "a fair reading of Lopez shows that the noneconomic, criminal nature of the conduct at issue was central to our decision in that case." ${ }^{46}$ Consistent with this observation, the constitutionality of PBABA may turn on the noneconomic, truly local nature of the conduct being regulated. At the very least, the intersection between the noneconomic nature of the regulated activity and the traditional role of the states in regulating that activity creates a strong presumption against the constitutionality of the congressional effort to regulate it.

\section{DID CONGRESS MAKE FINDINGS PERTAINING \\ TO THE PERCEIVED EFFECT OF PARTIAL-BIRTH ABORTIONS ON INTERSTATE COMMERCE?}

As part of its "independent evaluation of constitutionality under the Commerce Clause" the Court will "consider legislative findings, and indeed even committee findings, regarding effect

41. 529 U.S. at 618 .

42. Pegram v. Herdrich, 530 U.S. 211, 237 (2000).

43. Cf. New York State Conf. of Blue Cross \& Blue Shield Plans v. Travelers Ins. Co., 514 U.S. 645,705 (1995) (establishing a presumption against federal regulation of health care as a field traditionally left to the states).

44. 410 U.S. 113 (1973).

45. See, e.g., Harris v. McRae, 448 U.S. 297 (1980) (upholding authority of Congress to refuse to fund abortions under Medicaid).

46. 529 U.S. at 610 . 
on interstate commerce." ${ }^{, 47}$ The goal of this examination is to illuminate the congressional judgment that the regulated activity substantially affects interstate commerce. Such findings are neither necessary nor sufficient to establish constitutional validity. The more extensive the findings and the more detailed the evidentiary support, however, the more likely it is that a court will incorporate the congressional judgment into its application of the substantially affects test. ${ }^{48}$

PBABA does include extensive findings. ${ }^{49}$ However, none of those findings pertain to interstate commerce. Rather, they are designed as a response to what Congress perceived as the erroneous factual predicate of the Stenberg decision and to the legal question of whether the Court ought to defer to these alternative congressional findings. The House report accompanying PBABA does contain a brief description of the perceived effect on interstate commerce, ${ }^{50}$ and certainly a federal court would take that discussion into account when applying the substantially affects test.

According to the House report the performance of a partialbirth abortion has the following effects on interstate commerce:

"[B]ecause so few abortionists perform partial-birth abortions, women seeking to obtain a partial-birth abortion are more likely to have to travel out-of-State to find an abortionist willing to perform the procedure." 51

"[P]artial-birth abortions are usually performed in an outpatient clinic or facility which is likely to 'purchase medicine, medical supplies, surgical instruments, and other supplies produced in other States." ${ }^{52}$

"[A]bortionists who perform partial-birth abortions advertise their services across state lines."

Taken as a whole, these three assertions provide a clear picture of what the authors of the report perceived as the potential effects on interstate commerce-namely, interstate travel, pur-

47. Lopez, 514 U.S. at 562.

48. See, e.g., Heart of Atlanta Motel, Inc. v. United States, 379 U.S. 241, 253 (1964).

49. The Partial-Birth Abortion Ban Act of 2003, Pub. L. No. 108-105, $\$ 2,117$ Stat. 1201, 1201-06 (2003). (2003)

50. The Partial-Birth Abortion Ban Act of 2003, H.R. REP. No. 108-58, at 24-25

51. Id. at 24

52. Id. at 25 .

53. Id. 
chases, and advertising. That outline of potential interstate consequences is certainly clear enough to direct a court toward asking the right questions. For example: How much travel interstate is generated by the performance of partial-birth abortions? What is the extent of interstate purchases related to the performance of partial-birth abortions? To what extent is the interstate advertising of abortion services related to the procurement of partialbirth abortions? The report, however, provides insufficient factual information to begin to answer these questions. To extent that these assertions can be deemed "congressional committee findings," at best they direct our attention toward the questions to be asked but not toward the answers. That is a valuable service, of course, but not one that comes close to resolving the constitutional issue presented.

\section{DOES PBABA INCLUDE A JURISDICTIONAL ELEMENT AND, IF SO, IS THE PRESENCE OF \\ THE ELEMENT SUFFICIENT TO VALIDATE THIS EXERCISE OF CONGRESSIONAL POWER?}

As to the first question, the answer is "yes." The "in or affecting interstate or foreign commerce" language creates a jurisdictional element that requires the government to prove a connection with commerce in every prosecution under PBABA. The inclusion of this element distinguishes PBABA from the statutes in both Lopez and Morrison, neither of which included any reference to interstate commerce. The question then becomes whether the inclusion of this jurisdictional element is, in itself, sufficient to sustain PBABA. I think not for two related reasons, one general and the other specific to PBABA.

First, nothing in either Lopez or Morrison suggests that the presence of a jurisdictional element automatically guarantees a statute's constitutionality. The Lopez Court saw the value of a jurisdictional element as a device that could limit the reach of a statute "to a discrete set of" activities that "have an explicit connection with or effect on interstate commerce." ${ }^{54}$ But the Lopez Court did not hold or even suggest that the presence of such an element was sufficient to sustain the exercise of congressional power. The resolution of that question requires at least some examination of the jurisdictional element at issue. Similarly, in Morrison, the Court, noting the absence of a jurisdictional ele- 
ment in VAWA, observed that the inclusion of such an element "would lend support to the argument that [a particular prohibition] is sufficiently tied to interstate commerce." item lends support to a proposition is not to say that this item establishes that proposition. In short, from the Court's perspective, the presence of a jurisdictional element is useful, but neither necessary nor sufficient to sustain any particular exercise of the commerce power. That brings me to my second point-namely, the insufficiency of PBABA's jurisdictional element.

Some jurisdictional elements may fully resolve the constitutional inquiry. For example, a statute that made it a crime to engage in gender-based violence on an instrumentality of interstate commerce would surely be sustained as a "first category" regulation of interstate commerce, for the jurisdictional element fully embraces the entire constitutional standard. ${ }^{56}$ PBABA's jurisdictional element does not, however, fully embrace the applicable standard. The phrase "in or affecting interstate or foreign commerce" is notable for its failure to include the adverb "substantially," a word that the Lopez Court found to be constitutionally significant.

Within this [affecting commerce] category, admittedly, our case law has not been clear whether an activity must "affect" or "substantially affect" interstate commerce in order to be within Congress' power to regulate it under the commerce clause. We conclude, consistent with the great weight of our case law, that the proper test requires an analysis of whether the regulated activity "substantially affects" interstate commerce.

Even if a prosecutor could show that the performance of a particular partial-birth abortion affected interstate commerce, it would not necessarily follow that this abortion substantially affected interstate commerce. Nor would the satisfaction of this element establish that partial-birth abortions as a class satisfy the substantially-affects standard. In other words, the jurisdictional element does not resolve our constitutional dilemma for the simple reason that it does not ask the right question.

55. 529 U.S. at 612; see also id. ("Such a jurisdictional element may establish that the enactment is in pursuance of Congress' regulation of interstate commerce.") (emphasis added).

56. 529 U.S. at 613 n.5

57. 514 U.S. at 559 (citation omitted); accord Morrison, 529 U.S. at 609. 
Perhaps an example will help. Suppose a woman drives from Iowa to Nebraska to procure a partial-birth abortion. A reasonable argument could be made that the performance of the abortion affected interstate commerce-but for the abortion the woman would not have engaged in interstate travel. Yet this "reasonable argument" does not establish that the commerceaffecting abortion substantially affected interstate commerce or, more importantly, that such abortions as a class exert such an effect. Indeed, a single trip across the state line would seem rather trivial. In any event, PBABA's jurisdictional element does not in any fashion resolve the critical question-namely, whether the performance of partial-birth abortions, either singly or in the aggregate, substantially affects interstate commerce.

Hence, PBABA's jurisdictional element merely limits the scope of the proscription to commerce-affecting abortions; it does not validate the legislation as a measure that regulates matters that substantially affect interstate commerce. Given that PBABA's jurisdictional element does not resolve the constitutional dilemma, we move to the final question.

\section{DO PARTIAL-BIRTH ABORTIONS SUBSTANTIALLY AFFECT INTERSTATE COMMERCE?}

In Wickard v. Filburn, ${ }^{58}$ a farmer sought to enjoin enforcement of a marketing penalty imposed on "that part of his 1941 wheat crop which was available for marketing in excess of the marketing quota established for his farm" under the Agricultural Adjustment Act of 1938 (AAA). ${ }^{59}$ The penalty resulted from the farmer having sowed an excess of 239 bushels of wheat, which were then consumed on the farm. Among other things, the farmer argued that enforcement of the AAA against him was inconsistent with the commerce clause since the impact on interstate commerce of his 239 bushels of farm-consumed wheat was by itself trivial. After discussing the economics of the interstate wheat market, the Court disagreed:

The effect of consumption of homegrown wheat on interstate commerce is due to the fact that it constitutes the most variable factor in the disappearance of the wheat crop. Consumption on the farm where grown appears to vary in an amount greater than 20 per cent of average production.... The effect

58. 317 U.S. 111 (1942). For a detailed discussion of Filburn and its current relevance, see Jim Chen, Filburn's Legacy, 52 EMORY L.J. 1719 (2003).

59. 317 U.S. at 113. 
of the statute before us is to restrict the amount which may be produced for market and the extent as well to which one may forestall resort to the market by producing to meet his own needs. That appellee's own contribution to the demand for wheat may be trivial by itself is not enough to remove him from the scope of federal regulation where, as here, his contribution, taken together with that of many others similarly situated, is far from trivial. ... One of the primary purposes of the Act in question was to increase the market price of wheat and to that end to limit the volume thereof that could affect the market. It can hardly be denied that a factor of such volume and variability as home-consumed wheat would have a substantial influence on price and market conditions.... This record leaves us in no doubt that Congress may properly have considered that wheat consumed on the farm where grown if wholly outside the scheme of regulation would have a substantial effect in defeating and obstructing its purpose to stimulate trade therein at increased prices. ${ }^{60}$

The Lopez Court described Filburn as supporting the proposition that Congress may regulate intrastate, noneconomic activity when the regulation of that activity is "an essential part of a larger regulation of economic activity, in which the regulatory scheme could be undercut unless the intrastate activity were regulated." ${ }^{\prime 1}$ Under such circumstances, the aggregated effects of the intrastate, noneconomic activity can be considered in determining whether the activity substantially affects interstate commerce. ${ }^{62}$ The key is the presence of some larger economic scheme at which the regulation is directed. The Court refused to apply this principle in Lopez since GFSZA had "nothing to do with "commerce' or any sort of economic enterprise." ${ }^{13}$ In other words, because there was no larger economic scheme at stake, aggregation was not permissible. The Court also refused to apply Filburn's aggregation principle in Morrison, where it reiterated its view "that, in every case where we have sustained federal regulation under the aggregation principle ... the regulated activity was of an apparent commercial character." ${ }^{, 64}$ In short, under Filburn, and consistent with Lopez and Morrison, application of the aggregation principle requires that either the

\footnotetext{
60. Id. at 127-29.

61. 514 U.S. at 561.

62. Id.

63. Id.

64. 529 U.S. at 611 n.4
} 
regulated activity itself be economic or that its regulation be part of a larger regulation of economic activity.

Given that the activity regulated by PBABA - the performance of a partial-birth abortion-is noneconomic, and that its regulation is not in any manner part of a larger regulation of economic activity, Lopez and Morrison bar a court assessing the constitutionality of PBABA from considering the aggregate effects of partial-birth abortions on interstate commerce. Rather, the entire focus of the inquiry in any particular case must be on the single act on which the prosecution is based-namely, whether this specific partial-birth abortion substantially affected interstate commerce. Here, a variant of farmer Filburn's argument regarding trivial effects should prevail since the effect of any single partial-birth abortion on interstate commerce is likely to be insubstantial.

Even if one were to aggregate the effects of partial-birth abortions on interstate commerce, it is not clear that the substantially affects standard could be satisfied. The problem here is not conceptual, as it was in Lopez and Morrison where Congress sought to "pile inference upon inference" to establish the requisite connection with interstate commerce. ${ }^{65}$ Under PBABA there is no apparent need to pile inference upon inference. Instead, the "committee findings" in the House report accompanying PBABA focus attention on a relatively discrete causal chain between the performance of the abortion and interstate commerce. What is lacking under PBABA is a factual predicate sufficient to establish that the effect on interstate commerce is substantial. As noted previously, the key questions requiring factual elaboration are: How much travel interstate is generated by the performance of partial-birth abortions? What is the extent of interstate purchases related to the performance of partial-birth abortions? To what extent is the interstate advertising of abortion services related to the procurement of partial-birth abortions? Without the facts necessary to answer these questions, we cannot fully assess the connection between the performance of a partial-birth abortion and its effect on interstate commerce. At this point those facts have not been introduced into the defense of the statute.

In addition, to determine whether the performance of partial-birth abortions in the aggregate substantially affects interstate commerce, we will need to know how many such abortions

65. 514 U.S. at 567; see also Morrison, 529 U.S. at 614-15. 
are performed. In Stenberg $v$. Carhart, the Court observed that "[t]here are no reliable data on the number of [partial-birth] abortions performed annually. Estimates have ranged between 640 and 5,000 per year." ${ }^{, 66}$ A survey by the Alan Guttmacher Institute, a pro-choice organization, put the number at 2,200 for the year 2000, which is up from 363 in $1996 .{ }^{67}$ Pro-life advocates put the number somewhat higher. From a purely economic perspective, regardless of whose statistics one credits, these are not particularly large numbers given the overall size of the U.S. economy. One wonders whether they are sufficient, even in the aggregate, to establish a substantial effect on interstate commerce. By way of contrast, the Filburn Court concluded that wheat grown for consumption on the farm varied "in an amount greater than 20 per cent of annual [wheat] production" 68 and "that a factor of such volume and variability as home-consumed wheat would have a substantial influence on price and market conditions." ${ }^{69}$ The Court went on to detail why this was so. Significantly, the Lopez Court described Filburn as "perhaps the most far reaching example of Commerce Clause authority over intrastate activity." $"$ That being the case, the significantly weaker argument that partial-birth abortions exert a substantial effect on interstate commerce would seem to fall well short of the historical reach of the commerce power over intrastate activity. Of course, as I've noted several times, even this observation generously assumes that the Court will even consider the substantially affects argument given the noneconomic nature of the regulated activity.

\section{CONCLUSION}

The primary weakness to the claim that PBABA represents a valid exercise of the commerce power is that the activity regulated by PBABA - the performance of a partial-birth abortionis noneconomic as that term has been used by the Rehnquist

66. 530 U.S. at 929.

67. See Stanley K. Henshaw, Abortion Incidence and Services in the United States, 1995-1996, FAmily PlanNING PERSPECTIVES, Nov./Dec. 1998, at 263, available at http:/www.guttmacher.org/pubs/journals/3026398.html (363 D\&X abortions in 1996); Lawrence B. Finer \& Stanley K. Henshaw, Abortion Incidence and Services in the United States in 2000, PERSPECTIVES ON SEXUAL AND REPRODUCTIVE HEALTH, Jan./Feb. 2003, at 6,13 , available at http://www.guttmacher.org/pubs/journals/3500603.html (2,200 D\&X abortions in 2000).

68. 317 U.S. at 127.

69. Id. at 128 .

70. 514 U.S. at 560 . 
Court. Under Lopez and Morrison, this flaw is quite likely fatal to the claim of congressional power. And even if not fatal, the presumption of unconstitutionality established by the noneconomic nature of the regulated activity is further bolstered by a combination of the traditional role of the states in regulating violent crime and health care and by the relative weakness of the argument that partial-birth abortions substantially affect interstate commerce. To counter this presumption, PBABA's proponents will, at the very least, have to develop a factual record that fairly establishes the substantial relationship between the performance of partial-birth abortions and interstate commerce. Yet the noneconomic nature of the regulated activity may make it doctrinally impermissible to aggregate effects and thereby eliminate the possibility of using even a post hoc rationalization to satisfy the substantially affects test. In addition, while the presence of a jurisdictional element may lend some support to a claim of constitutionality, the jurisdictional element in PBABA falls short because it fails to require that the effect on commerce be substantial. Finally, it is also worth keeping in mind that Justice Thomas may not be willing to validate any exercise of congressional power under the substantially affects test, potentially aligning himself with the "liberal" wing of the Court in a challenge to PBABA. ${ }^{71}$

71. Morrison, 529 U.S. at 627 (Thomas, J., concurring). 